\section{Index to textbooks reviewed}

Advanced Organic Chemistry, Part A,

2nd Edn: Structure and Mechanisms

(by F.A. Carey and R.J. Sundberg)

Advanced Plant Physiology (M.B.

Wilkins, ed.)

Anatomy and Physiology, Vol. 1, 2nd Edn (by E.B. Steen and A. Montagu)

Animal Behavior: An Evolutionary Approach, 3rd Edn (by J. Alcock)

Antibodies: Their Structure and

Function (by M.W. Steward)

Aspects of a Stratigraphic System:

The Devonian (by D.L. Dineley)

Astrophysical Techniques (by C.R. Kitchin)

Astrophysics (by R. Bowers and T. Deeming)

Atlas of Invertebrate Macrofossils (J.W. Murray, ed.)

Bacteria, Plasmids, and Phages: An Introduction to Molecular Biology (by E.C.C. Lin et al.)

Basic Marine Biology (by A.A. Fincham)

Behavioural Ecology: An

Evolutionary Approach, 2nd Edn

(J.R. Krebs and N.B. Davies, eds)

Biogeography: An Ecological and Evolutionary Approach, 4th Edn (by C.B. Cox and P.D. Moore)

Biological Oceanographic Processes, 3rd Edn (by T.R. Parsons et al.)

Biology of Animal Behavior (by J.W. Grier)

Biology: An Introduction (by K.D. Johnson et al.)

Biology of Microorganisms, 4th Edn (by T.D. Brock et al.)

Biology: The Unity and Diversity of Life, 3rd Edn (by C. Starr and R. Taggart)

Bioscope, 2nd Edn (by T.A. Easton and C.E. Rischer)

Cell Biology, 2nd Edn (by G. Karp)

Cells and Organelles, 3rd Edn (by

E. Holtzman and A.B. Novikoff)

Chemistry of the Elements (by

N.N. Greenwood and A. Earnshaw)

Chloroplast Metabolism: The

Structure and Function of

Chloroplasts in Green Leaf Cells, revised edn (by B. Halliwell)

Chloroplasts (by J.K. Hoober)

Class Experiments in Plant

Physiology (by H. Meidner)

Classical Mechanics (by B.P. Cowan)

Community Structure and the

Niche (by P.S. Giller)

Concepts of Ecology, 3rd Edn (by

E.J. Kormondy)

Development of Nerve Cells and

Their Connections (by W.G. Hopkins

Textbook supplement - prices

Where possible both dollar prices in the United States and sterling prices in Britain are given in the bibliographical details for each book. Export prices will generally be higher. If a dollar or sterling price is not cited, the book is not available in one of the two countries. However readers should check both price and availability of books before ordering.

and M.C. Brown)

Developmental Biology, 2nd Edn (by L.W. Browder)

Developmental Control in Animals and Plants, 2nd Edn (C.F. Graham and P.F. Wareing, eds)

Ecology: Principles and Practice (by W.H. Dowdeswell) Introductory Text (by I.D. White et al.)

Enzyme Structure and Mechanism, 2nd Edn (by A. Fersht) the Bio-organic Chemistry (by R.W. Hanson)

. Physiology (by E.N. Marieb)

W.H. Hildemann)

27 Essentials of Physiology, 2nd Edn (by J.F. Lamb et al.)

Evolution: A Modern Synthesis (by W.H. Dowdeswell)

The Evolving Continents, 2nd Edn (by B.F. Windley)

oring Biology, 2nd Edn (by P.S. Camp and K. Arms)

A First Course in General Relativity (by B. Schutz)

From Cells to Atoms: An Illustrated Introduction to Molecular Biology (by A.R. Rees and M.J.E. Sternberg)

Darwin to Behaviourism: Psychology and the Minds of Animals (by R. Boakes)

40 An to Brain, 2nd Edn (by S.W. Kuffler et al.)

S. Wh Edn (by A.C. Stern et al.)

(by

General Relativity and Relativistic Astrophysics (by N. Straumann)

General Zoology, 6th Edn (by C.A. Villee et al.)

Genesis on Planet Earth: The Search for Life's Beginning, 2nd Edn (by W. Day)

The Genetic Code and Protein Biosynthesis, 2nd Edn (by B.F.C. Clark)

Genetic Engineering in Higher Organisms (by J.R. Warr)

Genetics, 2nd .Edn (by C.J. Avers)

Genetics, 3rd Edn (by U. Goodenough)

Genetics and Development (by J.H. Sang)

42 Geomorphology (by R.J. Chorley et al.)

The History of the Earth's Crust (by D.L. Eicher et al.)

Human Genetics (by E.A. Carlson)

Immunology: An Introduction (by I.R. Tizard)

Inorganic Chemistry: Principles of Structure and Reactivity, 3rd Edn (by J.E. Huheey)

Insect Biology: A Textbook of Entomology (by H.E. Evans)

Insect Physiology, 8th Edn (by V.B. Wigglesworth)

Integrated Principles of Zoology, 7th Edn (by C.P. Hickman et al.)

Introduction to the Algae, 2nd Edn (by H.C. Bold and M.J. Wynne)

Introduction to Molecular Immunology, 2nd Edn (by A. Nisonoff)
51 An Introduction to Recombinant DNA (by A.E.H. Emery)

Marine Biology (by H.V. Thurman and H.H. Webber)

Marine Ecological Processes (by I. Valiela)

Membranes and their Cellular Functions, 3rd Edn (by J.B. Finean et al.)

Microbiology, 4th Edn (by G.A. Wistreich and M.D. Lechtman)

Molecular Immunology: A Textbook (by M.Z. Atassi et al.)

The Nature of the Environment:

31 An Advanced Physical Geography (by A. Goudie)

Neuroethology (by J.M. Camhi)

Organic Chemistry (by G.M. Loudon)

Patterns of Human Heredity: An Introduction to Human Genetics (by J.R. Brennan)

J (by S.R. Elliott)

27 Physics of Planetary Interiors (by G.H.A. Cole)

33 The Physiology of Flowering Plants: Their Growth and Development, 3rd Edn (by H.E. Street and H. Öpik)

Physiology of the Human Body, 6th Edn (by A.C. Guyton)

Planets and Their Atmospheres: Origin and Evolution (by J.S. Lewis and R.G. Prinn)

Plant Molecular Biology (by D. Grierson and S. Covey)

51 Pollution of our Atmosphere (by B. Henderson-Sellers)

28 Population Biology: The Coevolution of Population Dynamics and Behavior (by J.M. Emlen)

Predation (by R.H. Taylor)

Prehistoric Europe (by T. Champion et al.)

Primate Behaviour and Social Ecology (by H.O. Box)

Principles of Ecology (by R.J. Putman and S.D. Wratten)

Principles of Neural Development (by D. Purves and J.W. Lichtman)

Psychological Testing (by J.R. Graham and R.S. Lilly)

The Solar System ( by B.W. Jones)

Solid State Chemistry and its Applications (by A.R. West)

Spectral Problems in Organic Chemistry (by R. Davis and C.H.J. Wells)

Structural Inorganic Chemistry, 5th Edn (by A.F. Wells)

The Techniques in Genetic Engineering Video Library ( $R$. Williamson, series ed.)

Themes in Biogeography (J.A. Taylor, ed.)

Theoretical Concepts in Physics (by M.S. Longair)

The Third Dimension in Organic Chemistry (by A. Bassindale)

The Universe of Galaxies: Readings from Scientific American (compiled by P.W. Hodge)

Vertebrate Natural History (by M.F. Willson)

Vertebrate Zoogeography and Evolution in Australasia (M. Archer and $G$. Clayton, eds)

A Workbook for Astronomy (by $\mathrm{J}$. Waxman) 